\title{
Alternativas à Redução da Regressividade do Imposto de Renda da Pessoa Física no Brasil
}

\section{Alternatives to Reducing the Income Tax Return of Individuals in Brazil}

\author{
Rosa Angela Chieza ${ }^{a}$ (iD \\ Rejane Franchescinia ${ }^{-1}$ \\ Dão Real dos Santos ${ }^{b}$
}

\begin{abstract}
Resumo: O Brasil, no passado recente, não implementou a redução das desigualdades de renda através de uma política tributária progressiva. Ao contrário, nos anos 1990, seguiu as orientações de organismos multilaterais, como o Fundo Monetário Internacional, de redução das alíquotas marginais do Imposto de Renda da Pessoa Física (IRPF), restringindo ainda mais o papel distributivo desse imposto, e, nos anos 2000, optou pela ótica do gasto, como alternativa à redução da desigualdade de renda no país. Diante disso e da visão da Teoria de Tributação Equitativa e a partir dos princípios constitucionais da isonomia e da capacidade contributiva, analisa-se a regressividade do IRPF a despeito das alíquotas marginais progressivas. Observa-se que a alíquota efetiva apresenta uma relação decrescente com o aumento da renda. A partir de rendas acima de 40 salários mínimos, quanto maior a renda, menor é a alíquota efetiva do IRPF, enquanto que, para contribuintes com renda acima de 320 salários mínimos, a alíquota efetiva do IRPF é de $2,1 \%$ e para contribuintes com faixa de renda entre 30 e 40 salários mínimos é de 10,5\%, ou seja cinco vezes maior. A partir disso, apresentam-se três simulações para a atualização da tabela de IRPF visando suprir as iniquidades desse tributo, consequentemente ampliando a arrecadação e contribuindo para o enfrentamento da crise fiscal do Estado.
\end{abstract}

Palavras-chave: Imposto de renda. Regressividade tributária. Justiça fiscal.

\begin{abstract}
Brazil, in the recent past, has not programmed the reduction of income inequalities through a progressive tax policy. On the contrary, in the 1990s, it followed the guidelines of Multilateral Organizations such as the International Monetary Fund, to reduce the marginal rates of Personal Income Tax (IRPF), further restricting the distributive role of this tax and, in the years 2000 , opted from the perspective of spending, as an alternative to the reduction of income inequality in the country. Given this and the view of the Theory of Equitable Taxation and from the constitutional principles of isonomy and contributory capacity the regressivity of the IRPF is analyzed in spite of progressive marginal rates. It is observed that the Effective Rate has a decreasing relation with the

a Universidade Federal do Rio Grande do Sul, Faculdade de Ciências Econômicas, Departamento de Economia e Relações Internacionais. Porto Alegre, Rio Grande do Sul, Brasil.

$\mathrm{b}$ Instituto Justiça Fiscal. Porto Alegre, Rio Grande do Sul, Brasil.
\end{abstract}


increase of income. From incomes above $40 \mathrm{SM}$, the higher the income, the lower the effective rate of the IRPF. While for taxpayers with income above $320 \mathrm{SM}$ the effective income tax rate is $2.1 \%$, for taxpayers with a income range between 30 and $40 \mathrm{SM}$, it is $10.5 \%$, that is five times higher. From this, we present three simulations for the updating of the IRPF Table to cover the iniquities of this tax, consequently, increasing the collection and contributing with the confrontation of the fiscal crisis of the State.

Keywords: Income tax. Tax regressiveness. Fiscal justice.

JEL Classification: $\mathrm{H} 00 ; \mathrm{H} 2 ; \mathrm{H} 24$.

\section{1 lntrodução}

A despeito da retomada do neoliberalismo como resposta para o enfrentamento da atual crise do capitalismo, o Brasil não implementou a redução das desigualdades de renda através de uma política tributária progressiva. ${ }^{1}$ Ao contrário, nos anos 1990, seguiu as orientações de organismos multilaterais, como o Fundo Monetário Internacional (FMI), de redução das alíquotas marginais do Imposto de Renda de Pessoa Física (IRPF) e, a partir dos anos 2000, a despeito da redução das desigualdades de renda no país, ela não foi obtida através de reformas tributárias ${ }^{2}$ progressivas que visam justiça fiscal.

A teoria da tributação equitativa (TTE) define justiça fiscal de acordo com a capacidade de pagamento do contribuinte e aponta que o melhor caminho para o Estado de bem-estar social arrecadar tributos é realizar a equidade horizontal e vertical através da capacidade contributiva individual sobre a renda. O Brasil, desde o final do Império e início da República, registra regressividade no Sistema Tributário Nacional, conforme aponta Bonfim (2008), publicado originalmente em 1907, Pochmann (2008) e Oliveira (2010). Uma das características da regressividade está na predominância dos impostos indiretos (II) sobre o total da arrecadação tributária do país. Além dessa origem de regressividade no Brasil, a hipótese desta pesquisa é que o IRPF, apesar de apresentar alíquotas marginas progressivas, contribui para a regressividade do Sistema Tributário Brasileiro (STB).

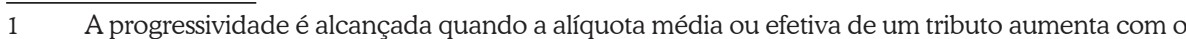
aumento da renda do contribuinte. Decorre daí que o tributo será regressivo se a alíquota média decresce com o aumento da renda e proporcional ou neutro se a alíquota média se mantém constante.

2 Por influência de leituras restritivas da literatura de tributação ótima, num contexto em que a revolução novo-clássica dos anos 1970 questionava toda a política fiscal do keynesianismo, construiu-se uma espécie de consenso no mainstream e entre os policymakers de que a política tributária, para não introduzir distorções do sistema econômico, deveria abster-se dos objetivos distributivos, transferindo-se ao gasto público essa função clássica da política fiscal (GOBETTI; ORAIR, 2016, p. 8). 
O IRPF foi aprovado no Brasil em 1922 e, desde então, passou por importantes mudanças, como, por exemplo, após a Constituição Federal de 1988, seguindo a orientação de organismos multilaterais de redução das faixas de renda e de alíquotas marginais: a tabela do IRPF no Brasil era composta por 13 faixas, ao passo que, hoje, por apenas cinco, (considerando a faixa de isenção). Diante disso, objetiva-se analisar a regressividade nas diferentes faixas de renda da Declaração do Imposto de Renda da Pessoa Física (DIRPF) no Brasil. Para tanto, utiliza-se a base de dados do IRPF Grandes Números - DIRPF de 2014: ano-calendário 2013, publicada pela Receita Federal do Brasil em 2014 e em 2016, ${ }^{3}$ A partir deste resultado, apresentam-se três simulações para a atualização da Tabela de IRPF visando suprir as iniquidades tributárias, bem como ampliar sua arrecadação e contribuir com a redução da crise fiscal.

Para se atingir os objetivos propostos, a seção 2 deste artigo aborda a teoria de tributação equitativa, a seção 3 descreve os aspectos históricos e normativos do IRPF no Brasil, a seção 4 apresenta a análise de dados de $O$ relatório grandes números DIRPF ano calendário 2013 (BRASIL, 2014b, 2016a), a seção 5 propõe, através de três simulações, uma nova tabela do IRPF no Brasil e, por fim, a seção 6 apresenta as considerações finais sobre o tema.

\section{A Teoria da Tributação Equitativa}

A teoria da tributação equitativa (TTE) representa uma base substancial para a formulação de sistemas tributários racionais em diversos países desenvolvidos. As proposições da TTE sobre a estruturação de um sistema tributário ideal fundamentam-se num catálogo de princípios elaborados por Neumark (1970), tendo como principal objetivo a justiça tributária e a igualdade, que devem ser realizadas segundo a capacidade de pagamento ou de contribuição. A tributação redistributiva é característica de um moderno Estado de bem-estar social, superando os limites do "Estado guarda-noturno" idealizado pelo liberalismo clássico. Para exercer suas múltiplas funções, o Estado deverá dispor dos recursos necessários, que são arrecadados na forma de tributos, sendo que estes são contribuições obrigatórias (e não preços), que, em regra, não garantem ao indivíduo, isoladamente, qualquer direito a uma contraprestação, uma vez que a TTE não incorpora a visão individualista de Estado. Os tributos constituem a consequência dos direitos e garantias que cabe ao Estado prover aos seus cidadãos. O tema central é como dividir o ônus da arrecadação dos recursos necessários à manutenção desse Estado de bem-estar social - justa distribuição da carga tributária -, de modo que a justiça e a igualdade sejam endossadas. No universo dos declarantes, os contribuintes

3 O relatório Grandes números IRPF 2014: ano-calendário 2013 foi publicado em 2014 e em 2016. Em 2016, incorporou três novas faixas de informações para rendimentos totais em SM, além das demais faixas que já compunham o referido estudo divulgado em 2014. 
estão em situação de desigualdade de renda antes da cobrança dos tributos. Sendo assim, será necessária uma unidade de medida que possibilite a cobrança dos tributos e a realização da justiça tributária. Como no centro da TTE está a justa distribuição da carga tributária, a qual deve ser realizada segundo a capacidade de pagamento do contribuinte, para determinar essa contribuição tributária devem ser seguidas duas regras que visam o tratamento igualitário aos contribuintes: no sentido horizontal - as pessoas da mesma condição econômica devem ser tratadas de forma igual; no sentido vertical - as pessoas em situação econômica diferente devem receber um tratamento diferente.

Assim, para constituir um sistema tributário racional com equidade é necessário que duas tarefas sejam cumpridas, as quais podem ser resumidas por duas indagações: o quê tributar? E como tributar? Na primeira pergunta define-se um indicador favorável que melhor estima a capacidade de pagamento do contribuinte, igualando-os horizontalmente. E na segunda pergunta definem-se as alíquotas e/ou regras especiais para a realização da equidade vertical. Como solução para a pergunta "o quê tributar?", a TTE aponta que a renda pessoal é o melhor indicador da capacidade de pagamento individual, seguida pelo patrimônio e o consumo. A definição de renda empregada aqui corresponde à da teoria do acrés-

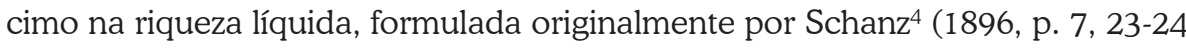
apud LAGEMANN, 2001), compondo-se por três conceitos de renda: utilidade, valor e consumo. A segunda questão, “como tributar?”, envolve a realização da justiça vertical. Para tal, dois critérios estão disponíveis para orientação: o poder aquisitivo econômico-financeiro individual e a utilidade individual. O primeiro critério é utilizado por Simons (1951 apud LAGEMANN, 2001) e Neumark (1970 apud LAGEMANN, 2001), consistindo numa tributação que emprega um sistema de alíquotas que causa aos indivíduos perdas relativamente iguais no seu poder aquisitivo. O segundo critério realiza a justiça vertical utilizando-se das teorias de sacrifício, a saber: a teoria do igual sacrifício marginal (sacrifício mínimo), a teoria do igual sacrifício absoluto e a teoria do igual sacrifício relativo (ou proporcional). Assim, o sistema de alíquotas deverá ser fixado de tal forma que as perdas de utilidade individual sejam iguais pela ótica marginal, absoluta ou proporcional.

No Quadro 1, apresenta-se uma síntese dos principais tributos defendidos pela TTE. A estruturação de um sistema tributário é composta por quatro principais bases de incidência: a renda, o consumo, as heranças e doações e o patrimônio. nance Analysis, ano 13, n. 1, p. 1- 87, 1896. 
Quadro 1 - Estruturação dos principais tributos segundo a Teoria da Tributação Equitativa

\begin{tabular}{|c|c|c|c|c|}
\hline Itens & $\begin{array}{l}\text { Imposto sobre } \\
\text { a Renda sobre } \\
\text { Pessoa Física }\end{array}$ & $\begin{array}{l}\text { Imposto sobre } \\
\text { o consumo }\end{array}$ & $\begin{array}{c}\text { Imposto sobre } \\
\text { heranças e } \\
\text { doações }\end{array}$ & Patrimônio \\
\hline $\begin{array}{l}\text { Base } \\
\text { econômica }\end{array}$ & $\begin{array}{l}\text { Ampla: renda no } \\
\text { conceito amplo. }\end{array}$ & $\begin{array}{l}\text { Ampla: gasto com } \\
\text { todos os bens e } \\
\text { serviços. }\end{array}$ & $\begin{array}{c}\text { Ampla: todas } \\
\text { as heranças e } \\
\text { doações (valor } \\
\text { real). }\end{array}$ & $\begin{array}{c}\text { Específico: a) apenas } \\
\text { o patrimônio sem } \\
\text { origem na poupança do } \\
\text { contribuinte; b) apenas } \\
\text { o patrimônio em posse } \\
\text { de pessoas naturais } \\
\text { (valor real). }\end{array}$ \\
\hline $\begin{array}{l}\text { Sistema de } \\
\text { alíquotas }\end{array}$ & Progressiva. & Única. & $\begin{array}{l}\text { Progressiva: } \\
\text { critério duplo: } \\
\text { grau de } \\
\text { parentesco e } \\
\text { valor da herança } \\
\text { ou valor do } \\
\text { patrimônio } \\
\text { preexistente. }\end{array}$ & $\begin{array}{l}\text { Levemente progressiva } \\
\text { (no caso de imposto de } \\
\text { renda sem declarações } \\
\text { separadas). Alíquotas } \\
\text { relativamente baixas: de } \\
\quad 0,5 \% \text { a } 1 \% \text {. }\end{array}$ \\
\hline $\begin{array}{l}\text { Parcela } \\
\text { isenta }\end{array}$ & $\begin{array}{l}\text { Mínimo de } \\
\text { existência. }\end{array}$ & $\begin{array}{c}\text { Para bens } \\
\text { e serviços } \\
\text { de primeira } \\
\text { necessidade, } \\
\text { alíquota isenta ou } \\
\text { nula. }\end{array}$ & $\begin{array}{c}\text { Para cada } \\
\text { herdeiro de } \\
\text { pequenos valores. }\end{array}$ & $\begin{array}{c}\text { Isenção para pequenos } \\
\text { valores. }\end{array}$ \\
\hline
\end{tabular}

Fonte: Elaboração própria a partir de Lagemann (2001).

Os tributos estão dispostos no Quadro 1 de acordo com a sua importância para a justiça tributária, ou seja, o IRPF é o principal imposto do sistema devido às suas características favoráveis para estimar a capacidade de pagamento individual e realizar a justiça horizontal. Os impostos sobre o consumo, heranças e doações e sobre o patrimônio compõem a lista de bases de incidência sugeridas pelos teóricos da TTE como a "second best". O sistema de alíquotas apresentado no Quadro 1 é caracterizado pela progressividade para os tributos diretos (renda, herança e doações, patrimônio), sobretudo no âmbito do IRPF devido ao seu papel central na justiça fiscal. Já para os tributos indiretos (consumo), a TTE propõe alíquota única. As isenções referentes ao mínimo de sobrevivência não é encarada pelos teóricos da TTE como uma forma de evasão do imposto. Propõe como indicadores para as faixas de isenção, renda mínima para a sobrevivência (no caso de incidência sobre a renda), cesta de bens e serviços de primeira necessidade (no caso de incidência sobre o consumo) e para pequenos valores (no caso de incidência sobre o patrimônio). A justificativa para a progressividade é explicada pelos teóricos da TTE como forma de efetivar a equidade vertical. Os argumentos usados para sustentar a escolha da progressividade são variados. De acordo com Simons (1951, p. 65 apud LAGEMANN, 2001), "[...] a progressividade do imposto de renda constitui 
a única medida efetiva para reduzir a desigualdade na distribuição da renda sem grandes prejuízos para a eficiência econômica e sem afetar o livre mercado [...]". Para Neumark (1970 apud LAGEMANN, 2001)5 p. 178-179 apud LAGEMANN, 2001), a progressividade fundamenta-se sob a perspectiva da teoria econômica: “[...] o postulado da progressividade é, em princípio, inseparável do princípio da capacidade de pagamento [...]".

Considerando-se que o IRPF é o tributo que melhor possibilita a aplicação do princípio da progressividade, segundo a TTE, aborda-se na seção 3, de forma não exaustiva, aspectos históricos sobre a regressividade do STB e a criação do IRPF no Brasil em 1922.

\section{A Regressividade do Sistema Tributário Brasileiro e o IRPF no Brasil: As- pectos Históricos}

A regressividade do STB é histórica. Os dados da Tabela 1 demonstram que, entre 1900 e 1905, a participação da tributação indireta ${ }^{6}$ na carga tributária bruta (CTB) era cerca de 90,2\%, atingindo 70\% no período entre 1941 e 1945.

Tabela 1 - Carga tributária bruta e distribuição entre impostos diretos e indiretos no Brasil (1900-1945)

\begin{tabular}{lcccccc}
\hline \multirow{2}{*}{ Periodos } & $\begin{array}{c}\text { Carga } \\
\text { tributária }\end{array}$ & \multicolumn{2}{c}{$\begin{array}{c}\text { Composição de tribu- } \\
\text { tos (\% do PIB) }\end{array}$} & $\begin{array}{c}\text { Participação (\%) na } \\
\text { carga tributária }\end{array}$ & \\
\cline { 3 - 5 } & (\% do PIB) & Indiretos & Diretos & Indiretos & Diretos & Total \\
\hline $1900-1905$ & 12,59 & 11,35 & 1,24 & 90,2 & 9,8 & 100 \\
$1906-1910$ & 12,41 & 11,18 & 1,23 & 90,1 & 9,9 & 100 \\
$1911-1915$ & 11,14 & 9,96 & 1,18 & 89,4 & 10,6 & 100 \\
$1916-1920$ & 7,00 & 6,07 & 0,93 & 86,7 & 13,3 & 100 \\
$1921-1925$ & 7,53 & 6,58 & 0,95 & 87,4 & 12,6 & 100 \\
$1926-1930$ & 8,89 & 7,68 & 1,21 & 86,4 & 13,6 & 100 \\
$1930-1935$ & 10,23 & 8,43 & 1,80 & 82,4 & 17,6 & 100 \\
$1936-1940$ & 12,50 & 9,92 & 2,58 & 79,4 & 20,6 & 100 \\
$1941-1945$ & 12,71 & 8,90 & 3,81 & 70,0 & 30,0 & 100 \\
\hline
\end{tabular}

Fonte: Elaboração própria a partir de Oliveira (2010).

Essa mudança na composição da estrutura tributária brasileira é explicada muito mais pela alteração no modelo de desenvolvimento econômico adotado no Brasil, cujo modelo alterou-se de "fora para dentro" com a adoção do processo de

5 NEUMARK, F. Grundsátze gerechter und õkonomisch rationaler Steuerpolitik. Tübingen: Mohr, 1970.

6 Como os impostos indiretos incidem sobre o consumo e os trabalhadores de baixa renda destinam grande parte de sua renda ao consumo, são estes que acabam comprometendo uma maior parte de suas rendas, em termos proporcionais, ao pagamento dos tributos. 
substituição de importações a partir da crise econômica mundial de 1929. A contração da atividade econômica provocada pela crise de 1929, com impacto negativo sobre o comércio internacional, em especial sobre a exportação do café, principal produto da pauta de exportação do país, prejudicou a arrecadação de imposto sobre o comércio exterior, e, assim, o “[...] governo começou gradativamente a explorar impostos internos para fortalecer suas receitas [...]". (OLIVEIRA, 2010, p. 13). Dentre os impostos internos, destaca-se a criação do Imposto de Renda (imposto direto) em dezembro de 1922, cuja "[...] cobrança foi estendida para os rendimentos de todas as pessoas físicas e jurídicas do país, estabelecendo-se, com a sua regulamentação, em 1923, alíquotas progressivas que variavam de 0,5\% a 8\%, sem diferenciar, porém, os rendimentos do capital e do trabalho [...]" (OLIVEIRA, 2010, p. 13). De outro lado, a Constituição Federal de 1934 limitou a alíquota do imposto de exportação (imposto indireto) em 10\%. Essa medida objetivava garantir maior competitividade do produto nacional no mercado externo, contribuindo, em parte, para reduzir a participação dos impostos indiretos na carga tributária total (CTT) da economia brasileira, conforme demonstrado na Tabela 1.

Os dados demonstrados na Tabela 2 apontam que, no início do século XXI, a situação de regressividade do Sistema Tributário Nacional (STN) permanece, a despeito de um conjunto de alterações tributárias ter sido implementado ao longo do século XX. Em 2014, do total da arrecadação, 77,80\% incidem sobre a base indireta (bens e serviços, folha de salários) e apenas $22,20 \%$ sobre a base de incidência direta (renda e propriedade).

Tabela 2 - Evolução da participação das bases de incidência na arrecadação total: 2005 a 2014 (em \%)

\begin{tabular}{lcccccccccc}
\hline Tipo de base & $\mathbf{2 0 0 5}$ & $\mathbf{2 0 0 6}$ & $\mathbf{2 0 0 7}$ & $\mathbf{2 0 0 8}$ & $\mathbf{2 0 0 9}$ & $\mathbf{2 0 1 0}$ & $\mathbf{2 0 1 1}$ & $\mathbf{2 0 1 2}$ & $\mathbf{2 0 1 3}$ & $\mathbf{2 0 1 4}$ \\
\hline Renda & 18,6 & 18,4 & 19,2 & 20,4 & 19,6 & 18,2 & 19,1 & 17,9 & 18,1 & 18 \\
Folha de salários & 23,7 & 24,1 & 23,8 & 23,9 & 25,7 & 25,4 & 25 & 25,7 & 25 & 25,2 \\
Propriedade & 3,3 & 3,5 & 3,5 & 3,5 & 3,9 & 3,8 & 3,7 & 3,9 & 3,9 & 4,2 \\
Bens e serviços & 49,4 & 49,1 & 48,4 & 50,2 & 49,1 & 50,4 & 50 & 50,6 & 51,2 & 51 \\
Transações financeiras & 4,8 & 4,8 & 4,8 & 2 & 1,8 & 2,1 & 2,2 & 2 & 1,7 & 1,6 \\
Outros tributos & 0,2 & 0,1 & 0,3 & 0 & 0 & 0,1 & 0,1 & 0 & 0 & 0 \\
\hline Receita tributária total & 100 & 100 & 100 & 100 & 100 & 100 & 100 & 100 & 100 & 100 \\
\hline
\end{tabular}

Fonte: Elaboração própria a partir de Brasil (2015).

Da mesma forma, os dados da Tabela 3 demonstram a participação dos tributos por base de incidência na CTT, que atingiu 33,47\% do PIB em 2014, explicita a predominância de tributos sobre a base indireta, contribuindo para a regressividade do STN. A tributação regressiva traz como consequências o encarecimento dos bens de consumo, afetando duplamente e de forma negativa o consumo das famílias de rendas médias e baixa e a competitividade das empresas brasileiras, 
uma vez que, em regra geral, se obrigam a competir com empresas localizadas na Europa e nos Estados Unidos, que, comparativamente com o Brasil, estão submetidas a uma menor tributação incidente sobre consumo (e maior sobre renda e capital). ${ }^{7}$ Esses dois aspectos negativos recaem duplamente sobre o contribuinte/ consumidor brasileiro, primeiro, de forma indireta, porque esse sistema tributário negligencia a tributação direta (sobre renda e capital) e privilegia a tributação indireta (sobre o consumo), onerando a produção interna, dificultando a geração de empregos e, de forma direta, elevando o preço final dos produtos.

Tabela 3 - Receita tributária e carga tributária bruta por base de incidência (2013 e 2014)

\begin{tabular}{lccccccc}
\hline \multirow{2}{*}{ Tipo de Base } & \multicolumn{3}{c}{$\mathbf{2 0 1 3}$} & \multicolumn{3}{c}{$\mathbf{2 0 1 4}$} \\
\cline { 2 - 8 } & \multirow{2}{*}{$\mathbf{R}$ milhões } & $\mathbf{\%}$ & \multirow{2}{*}{ \% } & \multirow{2}{*}{ R\$ milhões } & \% & PIB & \% \\
\hline Total da receita tributária & $1.740 .419,5$ & 33,74 & 100,00 & $1.847 .739,7$ & 33,47 & 100,00 \\
Tributos sobre a renda & $315.266,0$ & 6,11 & 18,11 & $332.879,7$ & 6,03 & 18,02 \\
Tributos sobre a folha de salários & $435.637,9$ & 8,45 & 25,03 & $465.301,8$ & 8,43 & 25,18 \\
Tributos sobre a propriedade & $68.510,1$ & 1,33 & 3,94 & $77.077,4$ & 1,40 & 4,17 \\
Tributos sobre bens e serviços & $891.141,9$ & 17,28 & 51,20 & $942.666,5$ & 17,07 & 51,02 \\
Tributos sobre transações financeiras & $29.162,9$ & 0,57 & 1,68 & $29.819,4$ & 0,54 & 1,61 \\
Outros tributos & 700,7 & 0,01 & 0,04 & $-5,2$ & 0,00 & 0,00 \\
\hline
\end{tabular}

Fonte: Elaboração própria a partir de Brasil (2015).

No Gráfico 1 demonstra-se o comportamento dos valores da faixa de isenção do IRPF, medida em salário mínimo (SM), e do limite de isenção. Apesar da tendência ascendente da faixa de isenção, o limite de isenção, medido por SM, apresenta queda em praticamente todo o período, demonstrando que houve uma redução da faixa de isenção (SM), isto é, rendas cada vez menores, em termos reais, passaram a ser tributadas pelo IRPF, incorporando cada vez mais contribuintes.

$7 \quad$ Nos países da Organização para a Cooperação e Desenvolvimento Econômico (OCDE), a participação (\%) de cada base de incidência na carga tributária é de 33,55\% sobre renda e lucros, 27,3\% sobre seguridade social e folha salarial, 5,4\% sobre propriedade, 32,9\% sobre bens e serviços e 0,9 sobre outros tributos. Já nos países da América Latina, a referida participação é de $26,4 \%$ sobre renda e lucros, $17,3 \%$ sobre seguridade social e folha salarial, 3,3\% sobre propriedade, 51,3\% sobre bens e serviços e 1,4 sobre outros tributos (CASTRO, 2014). 
Gráfico 1- Evolução das alíquotas e do limite de isenção do IRPF mensal (1996 a 2015)

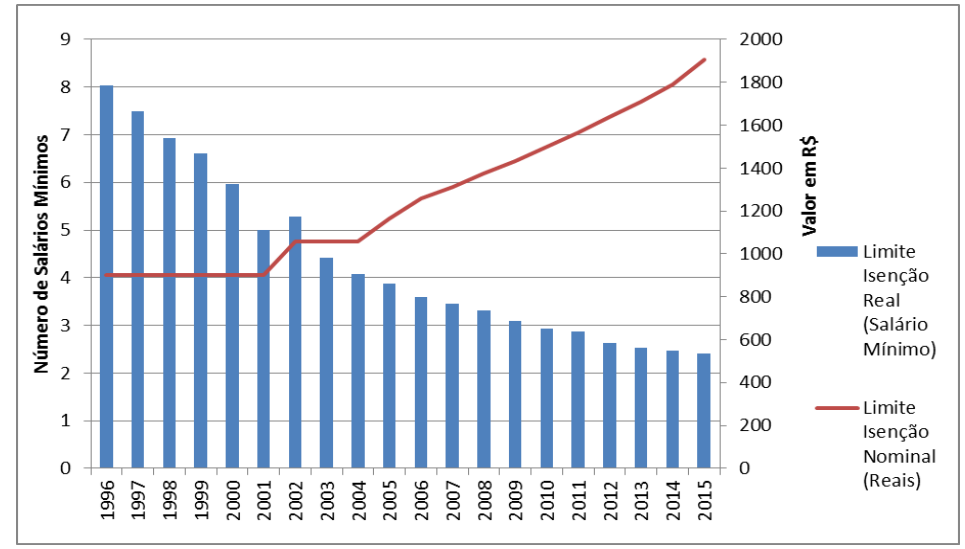

Fonte: Elaboração própria a partir de Brasil (2016b).

Como somente em 2016, a Receita Federal do Brasil (RFB) publicou dados mais detalhados sobre as Declarações do Imposto de Renda da Pessoa Física (DIRPF), através do relatório Grandes números DIRPF 2014: ano-calendário 2013 (BRASIL, 2014b, 2016a), possibilitando, assim, uma análise mais robusta do IRPF à luz dos princípios constitucionais da capacidade contributiva e da isonomia, bem como aos critérios ${ }^{8}$ tributários de generalidade, universalidade e progressividade conforme estabelece a Constituição Federal de 1988.

\section{Declaração do IRPF no Brasil: uma Análise}

Nesta seção apresentam-se análises estatísticas da DIRPF 2014 (BRASIL, 2016a), cuja síntese está na Tabela 4.

8 No inciso I, parágrafo $2^{\circ}$ do artigo 153, estão inclusos os critérios tributários generalidade, universalidade e progressividade. Segundo Difini (2003, p. 77), o critério da generalidade significa que o tributo deve abranger todos os contribuintes que pratiquem o ato ou estejam em igual relação com o fato descrito na hipótese de incidência. O critério da universalidade diz respeito à extensão da base de cálculo. Difini (2003, p. 77) entende que "[...] universalidade significa incidir o tributo sobre todos os fatos descritos na hipótese da incidência (no caso do imposto de renda, incidir indistintamente sobre diversas espécies de rendimentos). Tais princípios não impedem, todavia, a concessão de isenções objetivas ou subjetivas. Impedem é a exclusão apriorística de determinada categoria de pessoas ou rendimentos do rol dos sujeitos passivos ou dos fatos tributáveis". O critério da progressividade na definição de Machado (2004, p. 79) é o seguinte: "É progressivo o imposto cuja alíquota é maior na medida em que aumenta a base tributável. Como a base imponível é sempre uma expressão da riqueza de cada um, a progressividade faz com que o imposto onere mais quem tem riqueza maior [...]". 
Tabela 4 - Dados DIRPF 2013: categorias de renda por faixa de rendimentos totais (em milhões de reais)

\begin{tabular}{lcccccc}
\hline $\begin{array}{l}\text { Faixas de } \\
\text { rendimen- } \\
\text { tos (em SM) }\end{array}$ & $\begin{array}{c}\text { Quantidade } \\
\text { de } \\
\text { declarações }\end{array}$ & $\begin{array}{c}\text { Renda total } \\
\text { declarada }\end{array}$ & $\begin{array}{c}\text { Renda média } \\
\text { total declarada } \\
\text { (em reais) }\end{array}$ & $\begin{array}{c}\text { Renda } \\
\text { tributável } \\
\text { bruta }\end{array}$ & $\begin{array}{c}\text { Renda } \\
\text { tributável } \\
\text { exclusiva } \\
\text { na fonte }\end{array}$ & $\begin{array}{c}\text { Renda isenta } \\
\text { e não } \\
\text { tributável }\end{array}$ \\
\hline Até meio & 1.312 .686 & 442,39 & 337,01 & 344,25 & 34,28 & 63,87 \\
Meio a 1 & 504.536 & $3.747,44$ & $7.427,50$ & $3.468,94$ & 69,33 & 209,17 \\
1 a 2 & 1.077 .749 & $13.410,79$ & $12.443,33$ & $11.395,01$ & 451,40 & $1.564,38$ \\
2 a 3 & 2.577 .964 & $54.788,15$ & $21.252,49$ & $49.432,50$ & $1.491,50$ & $3.864,14$ \\
3 a 5 & 7.943 .447 & $249.469,84$ & $31.405,74$ & $215.316,00$ & $13.462,17$ & $20.691,67$ \\
5 a 7 & 4.187 .567 & $201.398,53$ & $48.094,40$ & $163.414,14$ & $13.725,06$ & $24.259,33$ \\
7 a 10 & 3.259 .844 & $220.709,34$ & $67.705,49$ & $171.570,76$ & $15.868,36$ & $33.270,22$ \\
10 a 15 & 2.448 .229 & $242.420,59$ & $99.018,76$ & $177.998,73$ & $18.273,46$ & $46.148,40$ \\
15 a 20 & 1.137 .873 & $159.608,09$ & $140.268,81$ & $110.112,47$ & $12.676,29$ & $36.819,33$ \\
20 a 30 & 1.048 .337 & $207.008,86$ & $197.464,04$ & $133.121,47$ & $17.465,90$ & $56.421,50$ \\
30 a 40 & 486.754 & $136.210,46$ & $279.834,28$ & $80.844,09$ & $11.941,00$ & $43.425,37$ \\
40 a 60 & 391.519 & $153.121,09$ & $391.094,92$ & $79.343,99$ & $14.587,53$ & $59.189,57$ \\
60 a 80 & 141.849 & $79.201,11$ & $558.348,00$ & $32.156,24$ & $8.470,66$ & $38.574,20$ \\
80 a 160 & 140.554 & $123.050,34$ & $875.466,67$ & $35.283,37$ & $14.891,53$ & $72.875,44$ \\
160 a 240 & 32.164 & $50.587,72$ & $1.572 .805,65$ & $9.989,46$ & $6.919,62$ & $33.678,64$ \\
240 a 320 & 13.643 & $30.521,06$ & $2.237 .122,18$ & $5.030,50$ & $4.486,57$ & $21.003,99$ \\
> 320 & 27.434 & $220.878,78$ & $8.051 .278,61$ & $22.936,74$ & $53.616,10$ & $144.325,93$ \\
\hline Total & 26.732 .149 & $2.146 .574,57$ & $80.299,36$ & $1.301 .758,67$ & $208.430,75$ & $636.385,15$ \\
\hline
\end{tabular}

Fonte: Elaboração própria a partir de Brasil (2016a).

Os rendimentos dos declarantes do IRPF são segregados em três grupos em função do tratamento tributário, renda tributável bruta, renda tributável exclusiva na fonte e renda isenta e não tributável. A renda total declarada foi de 2,1 trilhões de reais, distribuídos entre os três grupos de tratamento tributário. Chama a atenção que a fatia correspondente aos rendimentos isentos e não tributáveis representa $29,65 \%$ da renda total declarada (ver Gráfico 2). 
Gráfico 2 - Participação relativa dos tipos de rendimentos na renda total declarada (DIRPF 2013)

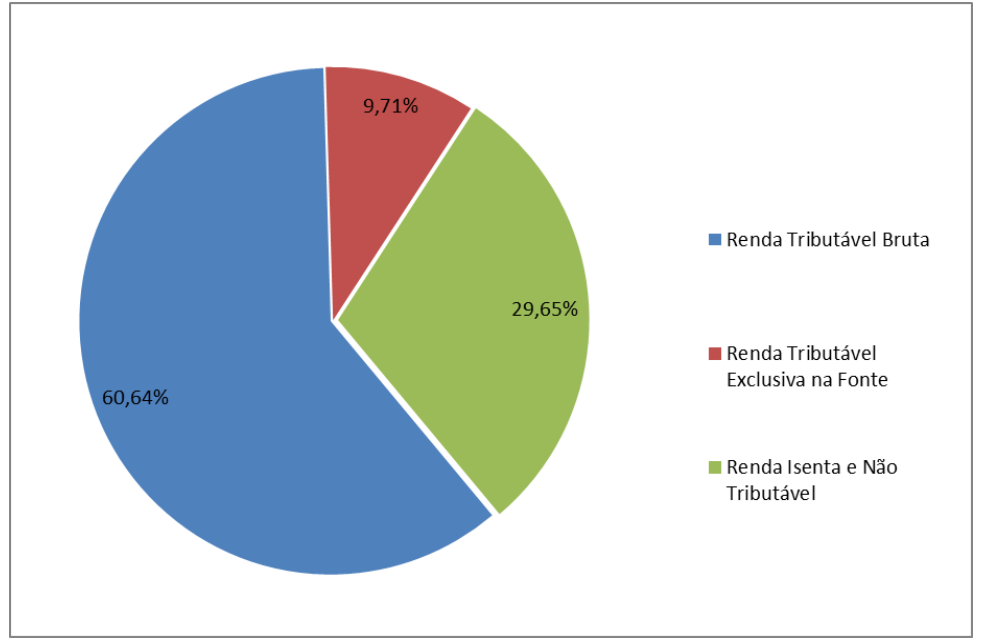

Fonte: Elaboração própria a partir de Brasil (2016a).

Nesses 29,65\% de renda isenta e não tributável, ressalta-se que o maior montante nominal de isenção está na categoria lucros e dividendos recebidos pelo titular e pelos dependentes, atingindo $\mathrm{R} \$ 231,3$ bilhões, ${ }^{9}$ algo em torno de $36,6 \%$ do total das isenções, conforme demonstrado na Tabela 5.

Tabela 5 - Categoria de rendimentos isentos e não tributáveis: DIRPF 2013 (Brasil, em reais)

\begin{tabular}{lcc}
\hline Categorias de renda & Valor & \% \\
\hline Lucros e dividendos recebidos pelo titular e pelos dependentes & 231,30 & 36,59 \\
Outros (especifique) & 58,12 & 9,19 \\
Rendimentos do sócio titular de microempresa ou de empresa de pequeno porte & 55,99 & 8,86 \\
Transferências patrimoniais: doações e heranças & 51,41 & 8,13 \\
Lucro na alienação de bens e direitos de pequeno valor & 44,13 & 6,98 \\
Parcela isenta prov. aposentadoria, declarantes 65 anos/mais & 42,93 & 6,79 \\
Pensão, prov. aposentadoria/reforma por moléstia grave & 33,55 & 5,31 \\
Parcela isenta correspondente à atividade rural & 33,05 & 5,23 \\
Indenizações por rescisão de contrato de trabalho e FGTS & 23,21 & 3,67 \\
Rendimentos de caderneta de poupança e letras hipotecárias & 20,69 & 3,27 \\
Incorporação de reservas ao capital/bonificações em ações & 15,94 & 2,52 \\
\hline
\end{tabular}

9 Como a divulgação de 2016 não incorporou a abertura da renda isenta e não tributável por categoria, utilizaram-se os dados divulgados em 2014 (ver Tabela 5), o que não compromete, metodologicamente, os resultados da pesquisa. 
conclusão.

\begin{tabular}{lcc}
\hline Categorias de renda & Valor & \% \\
\hline $\begin{array}{l}\text { Transferências patrimoniais: meação e dissolução da sociedade conjugal e da } \\
\text { unidade familiar }\end{array}$ & 8,03 & 1,27 \\
$\begin{array}{l}\text { Capital das apólices de seguro ou pecúlio por morte } \\
\text { Rendimento bruto até o máximo de 90\% da prestação de serviços decorrentes do }\end{array}$ & 3,75 & 0,59 \\
transporte de carga & 3,40 & 0,54 \\
$\begin{array}{l}\text { Bolsa de estudo e pesquisa } \\
\text { Restituição do imposto de renda de anos-calendário anteriores }\end{array}$ & 2,26 & 0,36 \\
$\begin{array}{l}\text { Bolsas de estudo e de pesquisa caracterizadas por doações recebidas por médicos- } \\
\text { residentes }\end{array}$ & 1,61 & 0,25 \\
$\begin{array}{l}\text { Rendimento bruto até o máximo de 40\% da prestação de serviços decorrentes do } \\
\text { transporte de passageiros }\end{array}$ & 0,72 & 0,12 \\
$\begin{array}{l}\text { 75\% rend trab. assal. receb em ME por serv. de autarquias ou repart. Gov. } \\
\text { Ganhos líq. oper. merc. à vista de ações negociadas em bolsas de valores }\end{array}$ & 0,60 & 0,09 \\
$\begin{array}{l}\text { Recuperação de prejuízo em renda variável } \\
\text { Imposto de renda ano-calendário ant. compensado jud. neste ano calendário }\end{array}$ & 0,33 & 0,05 \\
$\begin{array}{l}\text { Ganhos líq. oper. c/ouro, ativo financeiro, nas alienações realizadas até o valor estip. } \\
\text { Demais Rendimentos isentos e não tributáveis dos dependentes }\end{array}$ & $0,0,05$ & 0,05 \\
$\begin{array}{l}\text { Benefícios ind e reembolso desp. Receb. Voluntários Fifa da Susb Fifa Brasil } \\
\text { Rendimento bruto até o máximo de 60\% da prestação de serviços decorrentes do } \\
\text { transporte de carga }\end{array}$ & 0,00 & 0,01 \\
\hline Total de rendimentos isentos e não tributáveis & 0,00 & 0,000 \\
\hline
\end{tabular}

Fonte: Elaboração própria a partir de Brasil (2014b).

Essa isenção foi instituída pelo artigo 10 da Lei n 9.249, de 26 de dezembro de 1995 (BRASIL, 1995), ${ }^{10}$ a qual retira do campo de incidência do IRPF a renda auferida de lucros e dividendos da pessoa jurídica (PJ) transferidos à pessoa física (PF). Essa norma, além da perda potencial na arrecadação, sobretudo em relação às rendas auferidas de lucros e dividendos, afeta o cumprimento dos princípios constitucionais tributários da isonomia e da capacidade contributiva, bem como dos critérios da generalidade, universalidade e progressividade. A falta de isonomia no tratamento da renda declarada causa desigualdade nas alíquotas efetivas entre os contribuintes de menor e de maior renda, prejudicando a progressividade. A base de cálculo, assim, reflete uma falsa capacidade contributiva, não correspondendo à capacidade real de pagamento do contribuinte, devido ao benefício das isenções a partir da renda bruta declarada.

$10 \quad$ Art. 10: "Os lucros ou dividendos calculados com base nos resultados apurados a partir do mês de janeiro de 1996, pagos ou creditados pelas pessoas jurídicas tributadas com base no lucro real, presumido ou arbitrado, não ficarão sujeitos à incidência do imposto de renda na fonte, nem integrarão a base de cálculo do imposto de renda do beneficiário, pessoa física ou jurídica, domiciliado no País ou no exterior" (BRASIL, 1995, não paginado). 
Os dados do Gráfico 3 mostram que há uma relação crescente entre a renda total declarada e a renda isenta e não tributável, evidenciando que as isenções são mais elevadas para os contribuintes mais ricos. Para as faixas de renda total declarada superiores a $160 \mathrm{SM}$, aproximadamente $70 \%$ é isenta e não tributável.

Gráfico 3 - Razão entre o nível de renda isenta e não tributável e a renda total declarada por faixa de rendimento total (em \%)



Fonte: Elaboração própria a partir de Brasil (2016a).

De acordo com os dados do Gráfico 4, enquanto que, para os contribuintes com renda superior a $320 \mathrm{SM}$, o IRPF incidiu apenas sobre $8,1 \%$ de sua renda total declarada, para os contribuintes com rendas menores entre dois e três SM, o IRPF incidiu sobre $73,8 \%$ da renda total declarada. Esses dados explicitam a falta de equidade horizontal e o quanto, mesmo havendo alíquotas marginais progressivas, a base de cálculo é prejudicada, não sendo possível realizar a equidade vertical no IRPF. A redução da base de cálculo (renda tributável líquida), na medida em que aumenta a renda, decorre do tratamento não isonômico das rendas em função de sua origem, o que acarreta prejuízo na observância da equidade horizontal, afetando, assim, também a equidade vertical e representando um indicativo da regressividade no IRPF no Brasil. Em relação à alíquota efetiva ${ }^{11}$ do IRPF, os dados mostram progressividade nas faixas de dois a três SM até a faixa 30-40. No entanto, partir da faixa 40-60 SM, e na primeira faixa de até meio $\mathrm{SM}^{12}$, as alíquotas efetivas são regressivas

11 Alíquota efetiva é a razão entre o imposto devido e a renda total declarada.

12 Na primeira faixa de rendimentos totais auferidos de meio SM, a alíquota efetiva de IRPF é de 5,5\%. Chama atenção a discrepância do valor em relação às demais faixas. Cabe ressaltar que, para melhor compreensão, necessita-se da abertura das declarações individuais dessa faixa, no entanto, a RFB ainda não disponibiliza esse detalhamento dos dados da DIRPF 2013 (Brasil, 2014b). 
(razão entre o imposto devido e a Renda Total Declarada). Enquanto rendas maiores que 320 SM sofreram a incidência de uma alíquota efetiva de 2,13\%, o contribuinte com renda entre 30 e 40 SM foi tributado com uma alíquota efetiva de 10,5\%, ou seja, cinco vezes maior, demonstrando a regressividade do referido imposto.

Gráfico 4 - Razões entre a renda tributária líquida e o imposto devido sobre a renda total declarada do IRPF no Brasil: DIRPF 2014: ano-calendário 2013 (em \%)

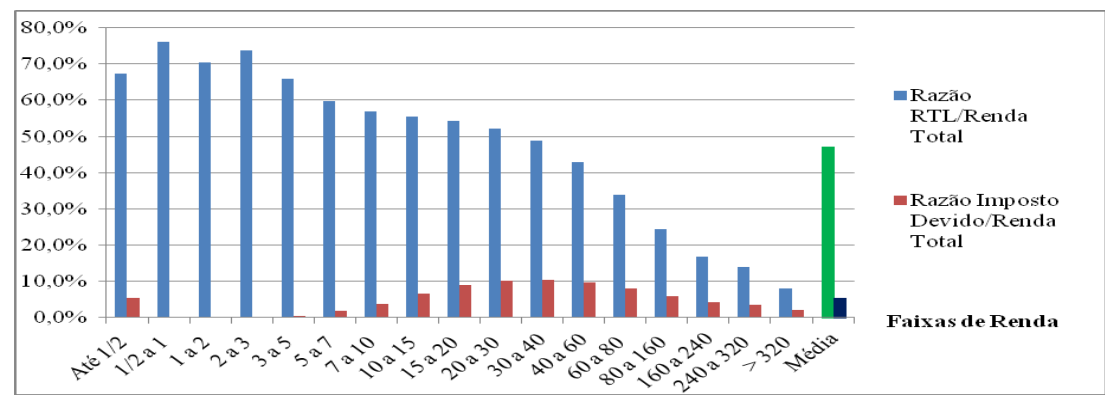

Fonte: Elaboração própria a partir de Brasil (2016a).

Diante do exposto, não surpreende a concentração de riqueza entre os declarantes do IRPF no Brasil, conforme demonstrado na Tabela 6.

Tabela 6 - Dados DIRPF 2013: renda tributária líquida, imposto devido e bens e direitos por faixa de rendimentos totais (em $\mathrm{R} \$$ milhões)

\begin{tabular}{|c|c|c|c|c|c|}
\hline $\begin{array}{l}\text { Faixas de } \\
\text { rendimentos }\end{array}$ & $\begin{array}{l}\text { Quantidade de } \\
\text { declarações }\end{array}$ & $\begin{array}{l}\text { Base de cálculo } \\
\text { (renda tributá- } \\
\text { ria liquida) }\end{array}$ & $\begin{array}{l}\text { Imposto } \\
\text { devido }\end{array}$ & $\begin{array}{l}\text { Bens e } \\
\text { direitos }\end{array}$ & $\begin{array}{l}\text { Valor médio de } \\
\text { bens e direitos } \\
\text { (em reais) }\end{array}$ \\
\hline Até $1 / 2$ & $1.312 .686,00$ & 298,37 & 24,18 & $102.134,37$ & 77.806 \\
\hline $1 / 2$ a 1 & $504.536,00$ & $2.852,84$ & 2,04 & $27.558,75$ & 54.622 \\
\hline 1 a 2 & $1.077 .749,00$ & $9.435,80$ & 4,92 & $63.809,96$ & 59.207 \\
\hline 2 a 3 & $2.577 .964,00$ & $40.412,54$ & 13,35 & $156.069,27$ & 60.540 \\
\hline 3 a 5 & $7.943 .447,00$ & $164.586,70$ & $1.159,75$ & $490.539,34$ & 61.754 \\
\hline 5 a 7 & $4.187 .567,00$ & $120.287,77$ & $3.688,27$ & $358.156,15$ & 85.528 \\
\hline 7 a 10 & $3.259 .844,00$ & $125.808,76$ & $8.350,79$ & $404.105,40$ & 123.965 \\
\hline 10 a 15 & $2.448 .229,00$ & $134.774,63$ & $16.303,12$ & $498.856,64$ & 203.762 \\
\hline 15 a 20 & $1.137 .873,00$ & $86.840,10$ & $14.229,75$ & $364.139,99$ & 320.018 \\
\hline 20 a 30 & $1.048 .337,00$ & $107.837,62$ & $20.834,70$ & $582.337,66$ & 555.487 \\
\hline 30 a 40 & $486.754,00$ & $66.430,54$ & $14.234,92$ & $354.222,46$ & 727.724 \\
\hline 40 a 60 & $391.519,00$ & $65.799,71$ & $14.915,80$ & $467.215,21$ & 1.193 .340 \\
\hline 60 a 80 & $141.849,00$ & $26.936,31$ & $6.333,37$ & $245.693,01$ & 1.732 .074 \\
\hline 80 a 160 & $140.554,00$ & $29.964,71$ & $7.257,15$ & $457.950,15$ & 3.258 .179 \\
\hline 160 a 240 & $32.164,00$ & $8.490,22$ & $2.119,96$ & $193.196,22$ & 6.006 .598 \\
\hline 240 a 320 & $13.643,00$ & $4.243,08$ & $1.072,27$ & $120.584,90$ & 8.838 .591 \\
\hline$>320$ & $27.434,00$ & $17.889,93$ & $4.699,55$ & $960.097,45$ & 34.996 .627 \\
\hline Total & $26.732 .149,00$ & $1.012 .889,61$ & $115.243,87$ & $5.846 .666,95$ & $218.712,94$ \\
\hline
\end{tabular}

Fonte: Elaboração própria a partir de Brasil (2016a). 
No Gráfico 5, ilustra-se a distribuição cruzada em dois eixos verticais do número de declarações e do valor médio de bens e direitos por declarante. O maior número de declarantes do IRPF está na faixa de renda de três a cinco SM, representando aproximadamente $30 \%$ do total de declarantes. Além disso, se a renda dos contribuintes com maiores rendas é menos tributada do que a renda das classes inferiores, é de se esperar que a maior concentração de riqueza, mensurada em bens e direitos, esteja nos níveis de renda mais elevados. Contribuintes com rendas superiores a $320 \mathrm{SM}$ são os que têm maior valor médio em bens e direitos de 35 milhões de reais. Denota-se, então, que a concentração de riqueza no Brasil tem relação, em parte, com a regressividade do IRPF, ${ }^{13}$ apesar de suas alíquotas marginais progressivas.

Gráfico 5 - Quantidade de declarações e valor médio de bens e direitos: faixa de rendimento total (DIRPF 2013)



Fonte: Elaboração própria a partir de Brasil (2016a).

Para melhor ilustrar a regressividade do IRPF, a qual é observada através da alíquota efetiva (imposto devido/renda total declarada), ${ }^{14}$ que demonstra a real ca-

13 Além da política tributária, outros fatores, como o gasto público, influenciam o índice de Gini. De acordo com Cepal (2015), no Brasil, o índice de Gini reduz 16,4 pontos percentuais após a intervenção do Estado (tributação e gasto público), sendo que o maior impacto distributivo decorre do gasto com educação, em primeiro lugar, seguido pelos gastos com aposentadorias e pensões públicas e com saúde, enquanto o sistema tributário por ser regressivo, é concentrador de renda. Além disso, outros aspectos culturais e políticos históricos como a atuação do Estado e os grupos de poder que se encastelam no seu interior contribuem para explicar o grau de desigualdade de renda do Brasil.

14 As rendas tributárias líquida e bruta, apesar de demonstradas no Gráfico 6, não representam a real capacidade econômica do contribuinte. 
pacidade de pagamento do contribuinte, observa-se, no Gráfico 6, que essa razão exibe formato em $U$ invertido, demonstrando a regressividade do IRPF, uma vez que, a partir de rendimentos entre 30 e $40 \mathrm{SM}$, quanto maior a renda total declarada, menor é a alíquota efetiva do IRPF. As ocorrências observadas na primeira faixa de renda (de meio a um SM) ${ }^{15}$ não devem ser consideradas, pois representam situações anômalas, uma vez que referem-se a uma faixa de renda inferior ao próprio limite de isenção.

Gráfico 6 - Alíquota efetiva para as rendas total declarada, tributária bruta e tributária líquida: DIRPF 2013 (em \%)

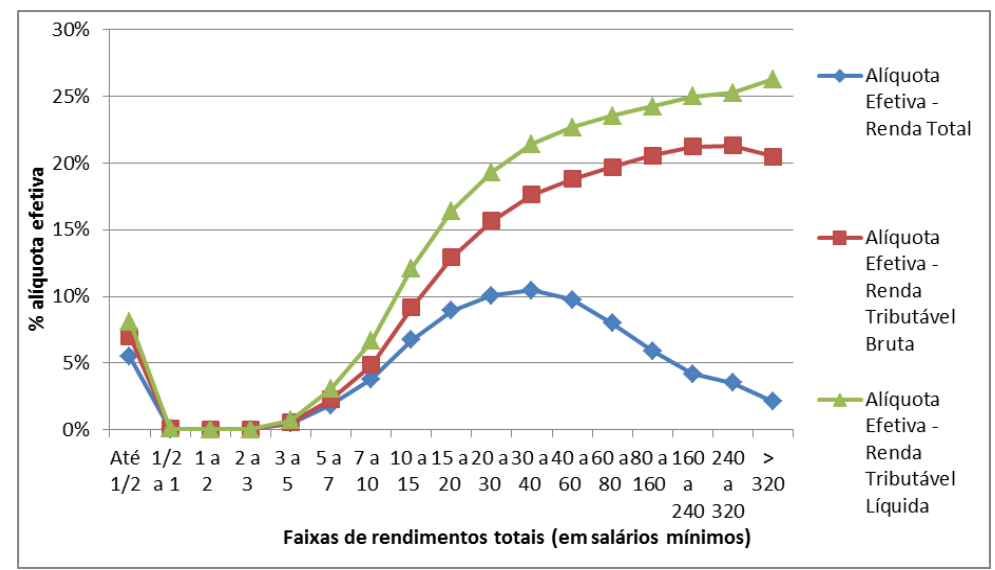

Fonte: Elaboração própria a partir de Brasil (2016a).

Tomando-se como referência a distribuição da carga tributária nos países da Organização para a Cooperação e Desenvolvimento Econômico (OCDE), percebe-se que, enquanto nesses países, a média de participação do IRPF é de aproximadamente $8,5 \%$ do PIB e $24,15 \%$ da carga tributária, no Brasil o IRPF responde por somente $2,7 \%$ do PIB e 7,6\% da CTB (CASTRO, 2014), revelando a importância e a potencialidade desse imposto para a construção de um sistema mais justo. Outro elemento relevante é que mais da metade de toda a renda tributável já se encontra na última faixa de alíquotas (27,5\%), que correspondia, em 2013, a rendas anuais superiores a $R \$ 49.051,80$, sendo que essa faixa representa $90 \%$ de todo o imposto devido (IJF, 2016). Esse dado revela a limitação da progressividade adotada atualmente, uma vez que a última faixa é extremamente abrangente, fazendo com que a curva da alíquota efetiva apresente tendência à horizontalidade a partir das faixas de 30 a 40 SM. Diante dessa progressividade negligenciada no IRPF, na seção 5 apresentam-se as propostas de alterações do IRPF.

15 Contribuintes que se enquadram na faixa de isenção, mas que receberam rendas decorrentes de ações judiciais, por exemplo, obrigam-se a declarar o IRPF. É por isso que esses rendimentos que, de acordo com a tabela do IRPF seriam isentos, estão inseridos nos dados abertos da DIRPF publicados pela Receita Federal do Brasil (Brasil, 2016a). 


\section{IRPF no Brasil: Proposições para uma Nova Tabela}

Nesta seção apresentam-se três simulações para uma nova tabela do IRPF visando corrigir os mecanismos causadores da regressividade, como a defasagem das faixas de base de cálculo, a vigência de alíquotas pouco expressivas para rendas altas e a subestimação da renda tributável líquida devido às grandes isenções da renda total declarada, aspectos identificados na análise da DIRPF 2013 (BRASIL, 2014b, 2016a) e analisados na seção 4 deste artigo. As alterações propostas baseiam-se no aperfeiçoamento das bases de cálculo do referido imposto, da efetivação da tributação sobre lucros e dividendos - além de outras rendas consideradas isentas e não tributáveis -, da ampliação da alíquota máxima e da ampliação das faixas de base de cálculo. Na seção 5.1 apresenta-se a metodologia e na seção 5.2, os resultados das simulações.

\subsection{Metodologia}

Para se utilizar os dados nas simulações, elaboraram-se as faixas da base de cálculo (R\$) utilizando-se a estrutura de informações por faixas de rendimentos em SM divulgada no referido relatório. Dessa forma, para se definir os valores dos intervalos das bases de cálculo multiplicou-se o valor do salário mínimo vigente em 2013 - que era de $\mathrm{R} \$ 678,00,{ }^{16}$ - pelo número de SM para cada uma das faixas de base de cálculo. A partir disso, em cada simulação agregaram-se os dados de uma ou mais faixas de renda para se recriar a tabela progressiva adotada nas simulações. As faixas de base de cálculo $(\mathrm{R} \$$ ) e as alíquotas (\%) das simulações foram definidas de acordo com o resultado do imposto devido e da alíquota efetiva para cada faixa sobre a renda total, comparativamente à alíquota efetiva e ao imposto devido para cada faixa na tabela de IRPF vigente no Brasil em 2013.

A primeira simulação visa o aumento da progressividade das bases de cálculo (renda tributária líquida) e a consecução da equidade horizontal por meio da hipótese de incorporação da parcela de renda isenta e não tributável (29,65\% da renda total declarada - ver Gráfico 2) nas bases de cálculo dos contribuintes por faixa de rendimento total. Com o propósito de se obter tratamento isonômico das rendas dos contribuintes, a partir da tabela do IRPF, ano-calendário 2013, altera-se o conceito de renda tributária líquida prevista na legislação em vigor, a qual é calculada a partir da renda total declarada, subtraindo-se a renda tributável exclusiva na fonte, a renda isenta e não tributável e as deduções legais. A mudança conceitual da renda tributária líquida (base de cálculo) justifica-se pelo fato de que a legislação vigente no Brasil, conforme abordado na seção 4, além de isentar lucros

16 Salário mínimo aprovado em 23 de dezembro de 2012, pelo Decreto $\mathrm{n}^{\circ} 7.872$, e vigente a partir de $1^{\circ}$ de janeiro de 2013. (Brasil, 2012). 
e dividendos desde 1995, corrobora a admissão de isenções de renda declarada sem demonstrar ausência de capacidade contributiva, provocando regressividade. Adicionalmente, os dados da Receita Federal (BRASIL, 2014b) mostram que, do total de $R \$ 632$ bilhões de renda isenta e não tributável (ver Tabela 5), em torno de $36 \%$ são provenientes de lucros e dividendos, comprometendo, assim, a equidade horizontal e vertical. Nesta simulação, como os dados da Tabela do IRPF estão disponibilizados por faixa de renda, em reais, e os dados estatísticos da publicação Grandes números da DIRPF 2013 (Brasil, 2014b, 2016a) estão disponibilizados por faixas de renda mensuradas em SM, realizou-se -se uma adequação em todas as faixas de renda e uma aproximação dos dados de renda nas faixas entre dois e sete SM, para que houvesse uma correspondência entre os dados da Tabela do IRPF vigente e os dados divulgados nos Grandes números.

Na segunda e a terceira simulações, mantém-se a ampliação da base de cálculo usada na primeira simulação, no entanto, na segunda simulação amplia-se a progressividade das alíquotas marginais de 4 a 50\% em 13 faixas e renda, mensuradas em SM, (considerando-se a isenção) e amplia-se a faixa de isenção em até cinco SM. Tanto a segunda simulação quanto a terceira objetivam ampliar a progressividade tributária do IRPF, visando desonerar os contribuintes das faixas com rendas menores e onerar os contribuintes das faixas de maior renda. A terceira simulação utiliza sete faixas (considerando-se a isenção) de renda, com alíquotas marginais progressivas de 10 a 50\%, com faixa de isenção de cinco SM. Em todas as simulações, consideraram-se as deduções legais, ou seja, a renda tributável bruta menos as deduções legais, resultando na nova renda tributável líquida, que nessas simulações incorpora a renda isenta e não tributável, ou seja, nas simulações tributa-se a renda isenta e não tributável e mantêm-se as deduções legais (despesas e saúde, educação por dependente). Além disso, não se agregam os rendimentos com tributação exclusiva.

\subsection{Propostas para uma Nova Tabela do IRPF que não negligencie a Progressividade}

De acordo com a metodologia da primeira simulação, parte-se da tabela do IRPF vigente na DIRPF 2013 (BRASIL, 2016b), demonstrada na Tabela 7, com cinco faixas de renda, considerando-se a faixa de isenção e com alíquotas marginais variando de $7,5 \%$ a $27,5 \%$.

Tabela 7 - Tabela do IRPF progressiva anual no Brasil (DIRPF 2013)

\begin{tabular}{llcl}
\hline Alíquota (\%) & \multicolumn{3}{c}{ Base de cálculo (R\$) } \\
\hline Isento & Até & $20.529,36$ \\
7,5 & De $20.529,37$ & até & $30.766,92$ \\
15 & De $30.766,93$ & até & $41.023,08$ \\
22,5 & De $41.023,09$ & até & $51.259,08$ \\
27,5 & De $51.259,09$ & até & \\
\hline
\end{tabular}

Fonte: Elaboração própria a partir de Brasil (2016b). 
Considerando-se a metodologia da primeira simulação (seção 5.1), com a utilização de nova base de cálculo (renda tributável líquida) que incorpora a renda isenta e não tributável observa-se uma alíquota efetiva progressiva, com um salto da progressividade na última faixa de renda. Isso decorre devido ao limite nominal da faixa superior da base de cálculo ser de apenas $\mathrm{R} \$ 51.259,08$ (ver Tabela 8), provocando aglomeração de contribuintes e da renda nessa faixa. No entanto, apesar da progressividade pouco distribuída entre as faixas de renda, essa proposta representaria um acréscimo nominal na arrecadação de $\mathrm{R}$ \$ 148,6 bilhões, representando um aumento de 128,96\% em relação à DIRPF 2013 (BRASIL, 2016a) (ver Tabela 8). Por fim, as desonerações seriam de apenas de $\mathrm{R} \$ 3$ bilhões, que correspondem à redução do imposto devido para as primeiras faixas de renda (faixa de até $\mathrm{R} \$ 51.259,08)$. O aumento de $\mathrm{R} \$ 148$ bi de imposto devido ocorreria na faixa de renda superior a $\mathrm{R} \$ 51.259,08$.

Tabela 8 - Base de cálculo, imposto devido e alíquota efetiva: primeira simulação (milhões de reais)

\begin{tabular}{|c|c|c|c|c|c|c|c|}
\hline Faixas & $\begin{array}{l}\text { Alíquota } \\
\text { (\%) }\end{array}$ & Renda total & $\begin{array}{l}\text { Base de cálcu- } \\
\text { lo simulação } 1\end{array}$ & $\begin{array}{c}\text { Imposto } \\
\text { devido } \\
\text { simula- } \\
\text { ção } 1\end{array}$ & $\begin{array}{c}\text { Imposto } \\
\text { devido } \\
2013\end{array}$ & $\begin{array}{l}\text { Alíquota efe- } \\
\text { tiva simula- } \\
\text { ção } 1 \text { (\%) }\end{array}$ & $\begin{array}{c}\text { Alíquota } \\
\text { efetiva } \\
2013(\%)\end{array}$ \\
\hline Até 20.529,36 & isento & $46.638,34$ & $37.379,71$ & - & 38,21 & - & 0,08 \\
\hline $\begin{array}{l}\text { De } 20.529,37 \text { até } \\
30.766,92\end{array}$ & $7,5 \%$ & $124.291,02$ & $93.185,74$ & 313,76 & 464,38 & 0,25 & 0,37 \\
\hline $\begin{array}{l}\text { De } 30.766,93 \text { até } \\
41.023,08\end{array}$ & $15,0 \%$ & $150.929,26$ & $111.023,10$ & 866,10 & 701,65 & 0,57 & 0,46 \\
\hline $\begin{array}{l}\text { De } 41.023,09 \text { até } \\
51.259,08\end{array}$ & $22,5 \%$ & $131.916,04$ & $94.084,92$ & $3.640,91$ & $2.415,82$ & 2,76 & 1,83 \\
\hline $\begin{array}{l}\text { Acima de } \\
51.259,08\end{array}$ & $27,5 \%$ & $1.692 .799,92$ & $1.307 .445,42$ & $259.044,65$ & $111.623,82$ & 15,30 & 6,59 \\
\hline Total geral & $\begin{array}{l}\text { Cinco } \\
\text { faixas }\end{array}$ & $2.146 .574,57$ & $1.643 .118,90$ & $263.865,42$ & $115.243,87$ & 12,29 & 5,37 \\
\hline
\end{tabular}

Fonte: Elaboração própria a partir de Brasil (2016a).

Observa-se que, segundo os dados da Tabela 8, contribuintes da faixa isenta apresentaram uma alíquota efetiva de 0,08\%. Esse dado fornecido pela fonte primária chama a atenção, no entanto, porque decorre de cobrança de imposto de renda decorrente de um fato gerador isolado ${ }^{17}$ que, no conjunto da renda do contribuinte, tornou-se indevido, uma vez que, mesmo com a renda adicional, continua inserido na faixa de isenção.

De acordo com a metodologia da segunda simulação, parte da nova base de cálculo (renda tributável líquida), considerada na primeira simulação, propõe uma

17 Por exemplo, um contribuinte com renda mensal que se enquadra na faixa de isenção, mas que está sendo tributado sobre a renda de uma indenização trabalhista, cujo IRPF foi descontado na fonte, será restituído no ajuste da declaração. 
tabela do IRPF com 13 faixas de renda e com alíquotas marginais variando entre 4 e 50\%, tendo como base os dados agregados da DIRPF 2013 (BRASIL, 2016a) conforme demonstrado na Tabela 9.

Tabela 9 - Proposta de tabela progressiva anual do IRPF para o Brasil: segunda simulação

\begin{tabular}{lccc}
\hline Alíquota (\%) & \multicolumn{3}{c}{ Base de cálculo (R\$) } \\
\hline Isento & Até & $\mathbf{4 0 . 6 8 0 , 0 0}$ \\
4 & De $40.680,01$ & até & $56.952,00$ \\
8 & De $81.952,01$ & até & $81.360,00$ \\
12 & De $122.040,01$ & até & $122.040,00$ \\
16 & De $162.720,01$ & até & $162.720,00$ \\
20 & De $244.080,01$ & até & $244.080,00$ \\
24 & De $325.440,01$ & até & $325.440,00$ \\
28 & De $448.160,01$ & até & $448.160,00$ \\
32 & De $650.880,01$ & até & $650.880,00$ \\
36 & De $1.301 .760,01$ & até & $1.301 .760,00$ \\
40 & De $1.952 .640,01$ & até & $1.952 .640,00$ \\
45 & Acima de $2.603 .520,01$ & & \\
50 & até & $2.603 .520,00$ \\
\hline
\end{tabular}

Fonte: Elaboração própria a partir de Brasil (2016a).

Os resultados da segunda simulação estão demonstrados na Tabela 10. Observa-se que haveria uma desoneração tributária para as faixas de renda até 40 $\mathrm{SM}$, logo cerca de $\mathrm{R} \$ 39,8$ bilhões deixariam de ser arrecadados dessas faixas de renda. Por outro lado, ocorreria oneração tributária das faixas superiores a 40 SM, representado um aumento de aproximadamente $R \$ 111,6$ bilhões de imposto devido, atendendo, assim, o objetivo de desonerar os contribuintes das faixas com rendas menores e de onerar os contribuintes das faixas de renda superiores, não atingidos na tabela do IRPF de 2013. O acréscimo nominal na arrecadação do IRPF seria de 71,7 bilhões, 62,28\% superior ao imposto devido em 2013.

Tabela 10 - Base de cálculo, imposto devido e alíquota efetiva: resultados da segunda simulação (milhões de reais)

\begin{tabular}{lccccccc}
\hline $\begin{array}{l}\text { Faixas } \\
\text { (SM ) }\end{array}$ & $\begin{array}{c}\text { Alíquota } \\
\text { (\%) }\end{array}$ & $\begin{array}{c}\text { Renda } \\
\text { total }\end{array}$ & $\begin{array}{c}\text { Base de } \\
\text { cálculo } \\
\text { simulaçao 2 }\end{array}$ & $\begin{array}{c}\text { Imposto } \\
\text { devido } \\
\text { simulação 2 }\end{array}$ & $\begin{array}{c}\text { Imposto } \\
\text { devido } \\
\mathbf{2 0 1 3}\end{array}$ & $\begin{array}{c}\text { Alíquota } \\
\text { efetiva } \\
\text { simulação } \\
\mathbf{2} \text { (\%) }\end{array}$ & $\begin{array}{c}\text { Alíquota } \\
\text { efetiva } \\
\text { 2013 (\%) }\end{array}$ \\
\hline Até 5 & Isento & $321.858,61$ & $241.588,56$ & - & $1.204,23$ & - & 0,44 \\
5 a 7 & 4 & $201.398,53$ & $143.641,10$ & - & $3.688,27$ & - & 1,83 \\
\hline & & & & & & & continua...
\end{tabular}

18 Na faixa de $4 \%$, não tem imposto devido, pois, apesar da base de cálculo atingir R\$143.641,10 para essa faixa de cinco a sete SM, individualmente cada contribuinte não atinge uma renda mensal nem de meio SM, por isso o imposto devido será zero (a razão entre R\$143.641,10 de imposto devido e número de declarantes resulta num valor inferior a cinco SM). 
conclusão.

\begin{tabular}{|c|c|c|c|c|c|c|c|}
\hline $\begin{array}{l}\text { Faixas } \\
\text { (SM ) }\end{array}$ & $\begin{array}{l}\text { Aliquota } \\
\text { (\%) }\end{array}$ & $\begin{array}{c}\text { Renda } \\
\text { total }\end{array}$ & $\begin{array}{c}\text { Base de } \\
\text { cálculo } \\
\text { simulaçao } 2\end{array}$ & $\begin{array}{c}\text { Imposto } \\
\text { devido }^{19} \\
\text { simulação } 2\end{array}$ & $\begin{array}{c}\text { Imposto } \\
\text { devido } \\
2013\end{array}$ & $\begin{array}{c}\text { Alíquota } \\
\text { efetiva } \\
\text { simulação } \\
2 \text { (\%) }\end{array}$ & $\begin{array}{c}\text { Alíquota } \\
\text { efetiva } \\
2013(\%)\end{array}$ \\
\hline 7 a 10 & 8 & $220.709,34$ & $158.627,02$ & $1.040,66$ & $8.350,79$ & 0,66 & 3,78 \\
\hline 10 a 15 & 12 & $242.420,59$ & $180.549,42$ & $4.882,93$ & $16.303,12$ & 2,70 & 6,73 \\
\hline 15 a 20 & 16 & $159.608,09$ & $123.340,08$ & $6.654,00$ & $14.229,75$ & 5,39 & 8,92 \\
\hline 20 a 30 & 20 & $207.008,86$ & $163.775,91$ & $13.580,83$ & $20.834,70$ & 8,29 & 10,06 \\
\hline 30 a 40 & 24 & $136.210,46$ & $109.438,93$ & $12.858,46$ & $14.234,92$ & 11,75 & 10,45 \\
\hline 40 a 60 & 28 & $153.121,09$ & $124.642,55$ & $18.829,02$ & $14.915,80$ & 15,11 & 9,74 \\
\hline 60 a 80 & 32 & $79.201,11$ & $65.380,78$ & $12.516,26$ & $6.333,37$ & 19,14 & 8,00 \\
\hline 80 a 160 & 36 & $123.050,34$ & $102.702,61$ & $24.984,74$ & $7.257,15$ & 24,33 & 5,90 \\
\hline 160 a 240 & 40 & $50.587,72$ & $42.112,76$ & $12.426,96$ & $2.119,96$ & 29,51 & 4,19 \\
\hline 240 a 320 & 45 & $30.521,06$ & $25.218,26$ & $8.213,26$ & $1.072,27$ & 32,57 & 3,51 \\
\hline$>320$ & 50 & $220.878,78$ & $162.100,92$ & $71.032,36$ & $4.699,55$ & 43,82 & 2,13 \\
\hline Total & 13 faixas & $2.146 .574,57$ & $1.643 .118,90$ & $187.019,50$ & $115.243,87$ & 11,38 & 5,49 \\
\hline
\end{tabular}

Fonte: Elaboração própria a partir de Brasil (2016a).

Na terceira simulação, utiliza-se a tabela do IRPF proposta na Tabela 11, com sete faixas de base de cálculo e com alíquotas marginais variando de 10 a 50\%, considerando-se uma faixa de renda de isenção de até cinco salários mínimos vigentes e o SM mensal vigente em 2013, que era de $\mathrm{R} \$ 678,00$. Assim como nas simulações anteriores, também aqui considera-se a nova base de cálculo (renda tributável líquida), que incorpora a renda isenta e não tributável.

Tabela 11 - Proposta de tabela progressiva anual do IRPF: terceira simulação

\begin{tabular}{cccc}
\hline Alíquotas (\%) & \multicolumn{3}{c}{ Base de cálculo (R\$) } \\
\hline Isento & - & Até & $40.680,00$ \\
10 & De $40.680,01$ & até & $81.360,00$ \\
16 & De $81.360,01$ & até & $162.720,00$ \\
23 & De $162.720,01$ & até & $325.440,00$ \\
31 & De $325.440,01$ & até & $650.880,00$ \\
40 & De 650.880,01 & até & $1.952 .640,00$ \\
50 & Acima de $1.952 .640,01$ & & - \\
\hline
\end{tabular}

Fonte: Elaboração própria a partir de Brasil (2016a).

Os resultados da terceira simulação encontram-se na Tabela 12. Observa-se uma mudança no caráter progressivo das alíquotas efetivas em todas as faixas de renda, uma vez que a DIRPF 2013 (BRASIL, 2016a) atinge apenas as faixas de até 40 SM. Além disso, ocorreria desoneração de IRPF nas classes inferiores de renda de cerca de $R$ \$ 30,7 bilhões e, em contrapartida, oneração de $R$ \$ 118,9 bilhões nas faixas superiores a partir de $40 \mathrm{SM}$, elevando em $76,53 \%$ o resultado do imposto

19 Na faixa de 4\%, não tem imposto devido, pois, apesar da base de cálculo atingir R \$ 143.641,10 para essa faixa de cinco a sete SM, individualmente cada contribuinte não atinge uma renda mensal nem de meio SM, por isso o imposto devido será zero (a razão entre $\mathrm{R} \$ 143.641,10$ de imposto devido e número de declarantes resulta num valor inferior a cinco SM). 
devido e representando um potencial adicional de arrecadação de $\mathrm{R} \$ 88,2$ bi em comparação à DIRPF 2013 (BRASIL, 2016a). A alíquota efetiva atingiria 12,38\%, superior aos 5,37\% da DIRPF 2013 (BRASIL, 2016a).

Tabela 12 - Base de cálculo, imposto devido e alíquota efetiva: resultados da terceira simulação (milhões de reais)

\begin{tabular}{lccccccc}
\hline $\begin{array}{l}\text { Faixas } \\
\text { (SM) }\end{array}$ & $\begin{array}{c}\text { Aliquota } \\
\text { (\%) }\end{array}$ & $\begin{array}{c}\text { Renda } \\
\text { total }\end{array}$ & $\begin{array}{c}\text { Base de } \\
\text { cálculo } \\
\text { simulação 3 }\end{array}$ & $\begin{array}{c}\text { Imposto } \\
\text { devido } \\
\text { simulação 3 }\end{array}$ & $\begin{array}{c}\text { Imposto } \\
\text { devido } \\
\text { 2013 }\end{array}$ & $\begin{array}{c}\text { Aliquota } \\
\text { efetiva simu- } \\
\text { lação 3 (\%) }\end{array}$ & $\begin{array}{c}\text { Aliquota } \\
\text { efetiva } \\
\text { 2013 (\%) }\end{array}$ \\
\hline Até 5 & Isento & $321.858,61$ & $241.588,56$ & - & $1.204,23$ & - & 0,37 \\
5 a 10 & 10 & $422.107,87$ & $302.268,12$ & - & $12.039,06$ & - & 2,85 \\
10 a 20 & 16 & $402.028,68$ & $303.889,50$ & $16.528,14$ & $30.532,87$ & 4,11 & 7,59 \\
20 a 40 & 23 & $343.219,32$ & $273.214,85$ & $31.615,66$ & $35.069,61$ & 9,21 & 10,22 \\
40 a 80 & 31 & $232.322,20$ & $190.023,32$ & $34.172,18$ & $21.249,18$ & 14,71 & 9,15 \\
80 a 240 & 40 & $173.638,06$ & $144.815,37$ & $39.798,63$ & $9.377,11$ & 22,92 & 5,40 \\
> 240 & 50 & $251.399,84$ & $187.319,17$ & $81.327,51$ & $5.771,81$ & 32,35 & 2,30 \\
\hline Total & Sete faixas & $2.146 .574,57$ & $1.643 .118,90$ & $203.442,14$ & $115.243,87$ & 12,38 & 5,37 \\
\hline
\end{tabular}

Fonte: Elaboração própria a partir de Brasil (2016a).

Das três simulações realizadas para uma nova tabela do IRPF, a terceira é a que combina os melhores resultados para progressividade das alíquotas efetivas e, ao mesmo tempo, maiores desonerações de IRPF para as menores faixas de renda e maiores onerações para as maiores faixas de renda.

\section{Considerações Finais}

No Brasil, o IRPF é o tributo com maior potencial para uma justiça fiscal efetiva. Porém, somente após a divulgação dos dados abertos da DIRPF pela primeira vez em 2016, foi possível identificar o grau de regressividade desse imposto, a despeito de suas alíquotas marginais progressivas. A divisão equitativa do ônus da arrecadação dos recursos tributários necessários à manutenção do Estado de bem-estar social, estabelecido na Constituição Federal de 1988, é fundamental para se alcançar a justiça e a igualdade, a fim de se obter mudanças que alterem a desigualdade de renda, riqueza e promova o acréscimo bem-estar social.

Além da necessidade de alterar o IRPF com faixas e alíquotas efetivas progressivas que cumpram os critérios e princípios estabelecidos na Constituição Federal de 1988 e que se pautem pela equidade horizontal e vertical, conforme estabelecida pela TTE, uma mudança dessa natureza representaria uma mudança substantiva de modelo de tributação que historicamente caracterizou-se pela regressividade.

As causas da regressividade estão, primeiramente, na "falsa" base de cálculo resultante da exclusão de em torno de $30 \%$ da renda total declarada, categorizadas como renda isenta e não tributável. Essa base de cálculo, que oculta a efetiva 
capacidade econômica dos contribuintes, (aprofundada pela Lei nº 9.249/1995) fere os princípios constitucionais de capacidade contributiva, generalidade, universalidade e progressividade, provocando iniquidades tributárias, uma vez que os contribuintes mais beneficiados com essa medida de isenção a partir da renda total são os de maior renda, chegando a representar aproximadamente $70 \%$ da renda total classificada como renda isenta e não tributável. Além disso, a Lei $n^{\circ}$ 9.249/1995, ao desonerar do imposto de renda os lucros e dividendos, estimulou a criação de pessoa jurídica individual (a pejotização), uma vez que o imposto sobre a renda do trabalho (pessoa física) é maior que o imposto que incide sobre a renda da pessoa jurídica constituída. Assim, a pejotição é consequência, não causa, de forma que a alternativa encontra-se na revogação da referida legislação e na retomada da tributação sobre a renda advinda de lucros e dividendos, atendendo, assim, ao princípios constitucionais da Carta Magna de 1988.

A base de cálculo em função da renda total para a faixa entre dois e três SM é de $89,66 \%$, enquanto que para a faixa de renda acima de 320 SM é de apenas 9\%. $\mathrm{Ou}$, enquanto para contribuintes com renda acima de $320 \mathrm{SM}$ a alíquota efetiva do IRPF é de $1,94 \%$ e $70 \%$ da sua renda declarada é isenta e não tributável, para contribuintes com faixa de renda entre 30 e 40 SM é de 10\%, ou seja, cinco vezes maior, e $32 \%$ da sua renda declarada é isenta e não tributável. Dessa forma, a classe que aufere renda decorrente do trabalho, na forma de salários, suporta maior participação relativa de sua renda para o IRPF, vis à vis classes com rendas mais elevadas.

Conforme demonstrado, o IRPF no Brasil possui agravantes como o limite de expansão do valor máximo da base de cálculo e uma alíquota máxima de apenas 27,5\%, patamar mais baixo dos países da $\mathrm{OCDE}^{20}$ e de países da América Latina ${ }^{21}$ como Chile e Argentina. Essas duas características tornam a tributação do IRPF no Brasil mais regressiva. Diante disso e das três simulações realizadas, a terceira simulação apresentou níveis de progressividade em todas as faixas de renda e um significativo acréscimo de imposto devido e potencial de arrecadação de $\mathrm{R} \$ 88$ bilhões. Além disso, supriria a defasagem das faixas de renda para a base de cálculo, uma vez que a faixa vigente de isenção de renda se alteraria da renda de isenção de $R \$ 20.529,36$ anuais prevista da DIRPF 2013 (BRASIL, 2016a) para a faixa de isenção de até $R \$ 40.680,00$. A alíquota efetiva média variaria progressivamente de 4,11\% a 32,35\% em contraposição ao quadro vigente na DIRPF 2013, que apresenta progressividade da alíquota efetiva somente nas faixas de dois a três SM até a faixa de 30 a 40 SM, sendo que a partir da faixa de 40 a 60 SM as alíquotas efetivas são regressivas. Essa proposta também altera a alíquota efetiva de 5,37 \% (DIRPF 2013 (BRASIL, 2016a) para 12,38\%.

20 A alíquota máxima do IRPF de países da OCDE é: Holanda (52\%), Bélgica (50\%), Japão (40\%) e França (45\%). Já no Brasil é de 27,5\% (CASTRO, 2014).

21 A alíquota máxima do IRPF na Argentina e no Chile é de 35\% e 40\%, respectivamente, enquanto no Brasil é de 27,5\% (CASTRO, 2014). 
Ressalta-se que, apesar do incremento de arrecadação que cada uma das simulações proporcionaria no IRPF, em qualquer uma delas a participação desse imposto sempre estaria abaixo de 5,5\% do PIB, ficando o Brasil distante da média dos países integrantes da OCDE, em que o IRPF representa em torno de 8,5\% do PIB.

As consequências da regressividade do IRPF vigente no Brasil resultam em concentração de riqueza (bens e direitos) e financiamento do Estado relativamente mais suportado pela classe que aufere a renda na forma de salários, uma vez que a renda advinda de dividendos, que representa o maior valor na categoria de rendimentos isentos e não tributáveis, é isenta do IRPF, produzindo uma excrescência, pois enquanto os contribuintes com rendas entre sete e dez SM arcam com uma alíquota efetiva de aproximadamente $4 \%$, os contribuintes com rendas superiores a 320 SM pagam somente $2,1 \%$. Paradoxalmente, o IRPF com alíquotas marginais progressivas trata os contribuintes de forma regressiva. Esses dados demonstram a urgência da adoção de tratamento isonômico das rendas, seja advindas do trabalho (salário), seja do capital (dividendos ou outras rendas), e distribuição proporcional do ônus e do bônus da tributação entre os cidadãos ${ }^{22}$ como alternativa para cumprir a Carta Magna de 1988.

Por fim, como esta proposta afeta de forma distinta contribuintes de diferentes níveis de rendas, espera-se distintas reações. A reação dos contribuintes no topo da pirâmide ( $1 \%$ mais ricos) ao deter maior poder político, poderiam inviabilizar uma proposta dessa natureza. A alternativa reside na formação da cidadania em educação fiscal para que a maioria dos contribuintes brasileiros, que pagam proporcionalmente mais tributos, possam exercer politicamente seu poder de forma mais qualificada. Por isso, uma proposta tecnicamente viável é necessária, porém, não suficiente, pois o tema exige um debate político com a sociedade, através do qual ela deve ser informada sobre as características históricas da regressividade do sistema tributário brasileiro e quais são as consequências de uma reestruturação tributaria mais progressiva sobre o crescimento econômico e a redução das desigualdades, resultando, assim, em apoio da maioria dos cidadãos brasileiros.

\section{Referências}

AFONSO, J. R. R. IRPF e desigualdade em debate no Brasil: o já revelado e o por revelar. Texto de Discussão - IBRE, n. 42, 2014. Disponível em http://bit.ly/1xatQFa. Acesso em: 11 dez. 2015.

22 Ver normas constitucionais tributárias, dentre as quais se destacam o não confisco (art. 150, inciso V), a uniformidade geográfica (art. 151, inciso I) e o princípio da capacidade contributiva (art. 45, $\left.\S 1^{\circ}\right)$. 
BOMFIM, M. A América Latina: males de origem. Rio de Janeiro: Centro Edelstein de Pesquisas Sociais, 2008. Disponível em: https://static.scielo.org/scielobooks/zg8vf/pdf/bomfim-9788599662786.pdf. Acesso em: 10 mar. 16.

BRASIL. Lei $n^{0}$ 9.249, de 26 de dezembro de 1995. Altera a legislação do imposto de renda das pessoas jurídicas, bem como da contribuição social sobre o lucro líquido, e dá outras providências. Brasília: Presidência da República, 1995. Disponível em: http://bit.ly/1OVDbq6. Acesso em: 10 dez. 2015.

BRASIL. Decreto $n^{0} 7.872$, de 26 de dezembro de 2012. Palácio do Planalto, 2012. Disponível em: http://www.planalto.gov.br/ccivil_03/_ato2011-2014/2012/decreto/d7872.htm. Acesso em : 11 dez. 2015.

BRASIL. Ministério da Fazenda. Receita Federal. Carga tributária no Brasil 2013: análise por tributo e bases de incidência. Brasília: Receita Federal, 2014a. Disponível em: http://migre. me/sn9FM. Acesso em: 11 dez. 2015.

BRASIL. Ministério da Fazenda. Receita Federal. Grandes números IRPF: anos-calendário 2007 - 2013. Brasília: Receita Federal, 2014b. Disponível em: http://migre.me/sn9KB. Acesso em: 11 dez. 2015.

BRASIL. Ministério da Fazenda. Carga tributária no Brasil 2014. Brasília: Receita Federal 2015. Disponível em: https://receita.economia.gov.br/dados/receitadata/estudos-e-tributarios-e-aduaneiros/estudos-e-estatisticas/carga-tributaria-no-brasil/29-10-2015-carga-tributaria-2014. Acesso em: 16 mar de 2016

BRASIL. Ministério da Fazenda. Receita Federal - CETAD. Grandes Números IRPF: anoscalendário 2013 (tabelas 06 a 10 - informações por faixas de salários mínimos). Brasília: Receita Federal, 2016a. Disponível em: < http://bit.ly/1Z3Qmct> . Acesso em: 26 maio 2016.

BRASIL. Receita Federal. Ministério da Economia. Memória da Receita Federal: história do imposto de renda: gráficos. Brasília: Receita Federal, 2016b. Disponível em: http://bit. ly/1q9YJaQ. Acesso em: 18 maio 2016.

BRASIL. [Constituição (1988)]. Constituição da República Federativa do Brasil de 1988. Brasília: Presidência da República, [2016c]. Disponível em: http://bit.ly/1OeOD3D. Acesso em: 9 jun. 2016.

CASTRO, F. A. Imposto de renda de pessoa física: comparações internacionais, medidas de progressividade e redistribuição. Dissertação (Mestrado em Economia do Setor Público) Departamento de Economia, Universidade de Brasília, Brasília, 2014. Disponível em: https:// repositorio.unb.br/bitstream/10482/16511/1/2014_F\%C3\%A1bioAvilaDeCastro.pdf. Acesso em: 11 dez. 2015.

CEPAL. Panorama fiscal de América Latina y el Caribe: dilemas y espacios de políticas. Santiago de Chile: CEPAL, 2015. Disponível em: https:/www.cepal.org/es/publicaciones/37747-panorama-fiscal-america-latina-caribe-2015-dilemas-espacios-politicas. Acesso em: 14 jun 2017

DIFINI, L. F. S. Manual de direito tributário. São Paulo: Saraiva, 2003, p. 77. 
GOBETTI, G. W.; ORAIR O. O. Progressividade tributária: a agenda negligenciada. Texto para Discussão - IPEA, n. 2190, p. 8, 2016.

INSTITUTO DE JUSTIÇA FISCAL (IJF). Isonomia entre as rendas, uma questão de justiça fiscal. Porto Alegre: IJF, 2016.

LAGEMANN, E. Tributação eqüitativa. Ensaios FEE, v. 22, n. 1, p. 288-306, 2001. Disponível em: http://bit.ly/1RIGUKh. Acesso em: 11 dez. 2015.

MACHADO, H. B. Os princípios jurídicos da tributação na constituição de 1988. 5 ed. São Paulo: Dialética, 2004, p. 79.

NEUMARK, F. Grundsátze gerechter und õkonomisch rationaler Steuerpolitik. Tübingen: Mohr, 1970.

OLIVEIRA, F. A. A evolução da estrutura tributária e do fisco brasileiro: 1889-2009. Texto para Discussão - IPEA, n 1469, p. 13, 2010.

POCHMANN, M. Tributação que aprofunda a desigualdade. Carta Social e do Trabalho Cesit, n. 8, p. 5-9, 2008. Disponível em: http://cesit.net.br/wp/wp-content/uploads/2014/11/ Carta-Social-e-do-Trabalho-8.pdf. Acesso em: 11 dez. 2015.

Recebido em: 16/04/2018.

Aceito em: 30/09/2019.

\section{(cc) BY}

